\title{
Pola Pembinaan Olimpiade Sains Nasional Matematika SMP di Kabupaten Ponorogo
}

\author{
Uki Suhendar $^{1 *}$, Arta Ekayanti², dan Senja P Merona ${ }^{3}$ \\ 1,2,3Program Studi Pendidikan Matematika, Universitas Muhammadiyah Ponorogo \\ Jalan Budi Utomo No 10, Ronowijayan, Siman, Ponorogo, Jawa Timur, Indonesia \\ 1*ukisuhendar90@gmail.com, 2arta_ekayanti@ymail.com, ${ }^{3}$ senjaputrimerona@gmail.com
}

Artikel diterima: 29-11-2019, direvisi: 09-01-2020, diterbitkan: 31-05-2020

\begin{abstract}
Abstrak
Masih banyak guru yang kebingungan menentukan pola pembinaan yang harusnya mereka lakukan. Penelitian ini bertujuan untuk mengetahui pola pembinaan Olimpiade Sains Nasional (OSN) Matematika SMP di Kabupaten Ponorogo. Penelitian ini merupakan penelitian deskriptif kualitatif. Pemilihan sampel dilakukan dengan purposive sampling. Instrumen yang digunakan adalah lembar wawancara. Analisis data dilakukan secara deskriptif kualitatif. Pola pembinaan OSN Matematika SMP di Kabupaten Ponorogo dilakukan dalam tiga pola pembinaan, yakni otoriter, permisif, dan demokratis. Pada pola otoriter, terlihat dari kebijakan sekolah dalam menyusun program pembinaan, proses seleksi, hingga reward yang diberikan ketika lolos seleksi OSN tingkat Kabupaten. Pola permisif terlihat dari kegiatan pembinaan yang memberikan kesempatan bagi siswa secara terbuka untuk menambah kemampuan di luar pembinaan di sekolah. Terakhir adalah pola demokratis, yang terlihat saat sebagian besar proses pembinaan diawali pemberian materi, lalu siswa diberi kesempatan menyelesaikan soal latihan. Selanjutnya dilakukan pembahasan soal yang telah dikerjakan siswa.

Kata Kunci: Kabupaten Ponorogo, OSN Matematika, pola pembinaan, SMP.
\end{abstract}

\section{The Pattern of Fostering the National Mathematics Science Olympiad in Junior High School in Ponorogo Regency}

\begin{abstract}
There are still many teachers who are confused about determining the pattern of coaching they should do. This research aims to determine the pattern of fostering the National Mathematical Science Olympiad (OSN) Junior High School in the Ponorogo Regency. This is qualitative descriptive research. The sample selection is done by purposive sampling. The instrument used was an interview sheet. Data analysis was performed descriptively qualitatively. The pattern of fostering the OSN Mathematics Junior High School in the Ponorogo Regency is carried out in three coaching patterns, namely authoritarian, permissive, and democratic. In the authoritarian pattern, it can be seen from the school's policy in developing a coaching program, the selection process, to the rewards given when passing OSN selection at the district level. Permissive patterns can be seen from coaching activities that openly provide opportunities for students to add skills beyond coaching at school. The last is a democratic pattern, which is very visible when most of the coaching process begins with the provision of material, then students are allowed to complete practice questions. Then a discussion on the questions the students have done is only done.
\end{abstract}

Keywords: Ponorogo Regency, OSN, the Pattern of Fostering, Junior High School. 


\section{Pendahuluan}

Kualitas sekolah erat kaitannya dengan prestasi yang diperoleh siswa-siswanya. Prestasi di sini meliputi prestasi akademik maupun non-akademik (Faturohman \& Afriansyah, 2020). Masih banyak sekolah yang tidak melakukan pembinaanpembinaan bagi siswanya sebelum mengikuti perlombaan. Padahal berdasarkan hasil pengabdian oleh Mardiyana, dkk. (2016), disimpulkan bahwa pembinaan olimpiade bagi siswa, khususnya bidang matematika, perlu dikelola oleh guru dengan baik, kontinu, dan berkesinambungan.

Salah satu prestasi akademik siswa SMP diperoleh dari kejuaraan pada Olimpiade Sains Nasional (OSN). Yang mana ini dapat diikuti setelah lolos dari seleksi tingkat sekolah, kabupaten, provinsi, hingga nasional (Yunita, 2014). Salah satu mata pelajaran yang dikompetisikan adalah mata pelajaran matematika. Soal OSN yang diberikan merupakan soal-soal yang butuh kemampuan penalaran dan kemampuan berpikir kritis. Oleh sebab itu, dalam persiapan menuju olimpiade, maka siswa harus memiliki ketekunan, kreativitas, komunikatif, dan pemahaman konsep (Kusuma, 2010). Sesuai dengan tujuan matematika diantaranya melatih kemampuan siswa dalam berpikir kritis dan kreatif (Budiono \& Suhendar, 2019).

Berdasarkan hasil pengabdian masyarakat tahun sebelumnya diperoleh bahwa sebagian besar guru matematika SMP di Kabupaten Ponorogo telah melakukan pembinaan atau mempersiapkan siswa-siswanya untuk berprestasi mengikuti OSN. Namun, masih kesulitan dalam proses pembinaan. Masih banyak guru yang kebingungan menentukan pola pembinaan yang harusnya mereka lakukan.

Pola pembinaan yang tepat tentu akan membantu proses pembinaan agar menghasilkan prestasi yang bagus. Menurut Soetopo \& Soemanto (dalam Hamdan, 2014), pembinaan adalah kegiatan yang dilakukan untuk meningkatkan apa yang sudah ada kepada yang lebih baik (sempurna) baik dengan melalui pemeliharaan dan bimbingan terhadap apa yang sudah ada (yang sudah dimiliki). Menurut Kurniawati (2014), program kegiatan pembinaan OSN sejalan dengan upaya pengarahan kemampuan daya saing dan kreativitas pada penguasaan ilmu pengetahuan dan teknologi yang dimiliki siswa. Siswa yang mengikuti pembinaan baik di tingkat sekolah, tingkat kabupaten, propinsi dan nasional inilah yang akan berkesempatan mengikuti ajang OSN di tiap tingkatan (Hartawan dkk., 2017).

Menurut Munandar (2018), pola pembinaan, dalam bidang keagamaan, dapat menggunakan strategi: pengajaran, pelatihan, dan pengasuhan. Strategi ini memungkinkan untuk diterapkan dalam pembinaan OSN khususnya bidang matematika. Fauzan \& Dzikrullah (2018) memilih metode dalam melakukan pembinaan dengan menggunakan sistem 
pendampingan secara berkala. Sedangkan Enung (2008) menyatakan bahwa pola pembinaan ada tiga jenis, yakni otoriter, permisif, dan demokratis.

Masih sedikit juga pembahasan ilmiah terkait pola pembinaan OSN di bidang matematika, khususnya di Kabupaten Ponorogo. Oleh karena hal tersebut, maka dalam penelitian ini ingin dideskripsikan pola pembinaan Olimpiade Sains Nasional (OSN) Matematika SMP di Kabupaten Ponorogo. Diharapkan guru ataupun pihak sekolah dapat memanfaatkan hasilnya sebagai referensi maupun evaluasi bagi mempersiapkan siswa-siswanya dalam OSN mata pelajaran Matematika. Yang mana tujuan akhirnya adalah siswa-siswa mampu berprestasi di OSN Matematika tingkat SMP.

\section{Metode}

Penelitian deskriptif kualitatif ini dilakukan untuk mengetahui pola pembinaan OSN Matematika SMP di Kabupaten Ponorogo. Data yang digunakan adalah data hasil wawancara terkait dengan pola pembinaan OSN Matematika. Untuk melakukan wawancara ini dibuat instrumen berupa pedoman wawancara (Afriansyah, 2016). Lembar wawancara ini berupa pertanyaanpertanyaan terbuka terkait pelaksanaan pembinaan OSN Matematika di sekolah responden.

Pemilihan responden menggunakan teknik purposive sampling. Pemilihan sampel bertujuan untuk menemukan pola pembinaan OSN Matematika, sehingga dipilih perwakilan dari sekolah yang lolos maupun tidak lolos seleksi OSN tingkat Kabupaten Ponorogo di tahun 2018 dan 2019. Penelitian ini mengambil sampel 8 sekolah yang merepresentasikan populasi. Alasannya adalah 4 SMP yang pernah lolos OSN tingkat kabupaten dalam 2 tahun terakhir berdasarkan data pengumuman dari Dinas Pendidikan Kabupaten Ponorogo. Sebagai pembanding maka dipilih 4 SMP yang belum lolos OSN tingkat kabupaten.

Penyusunan pedoman wawancara menjadi 3 bagian sesuai dengan sumber informasi, yakni untuk kepala sekolah, guru pembina OSN, dan siswa yang mengikuti pembinaan di sekolah. Untuk pedoman wawancara terdiri dari 11 butir pertanyaan. Bagi guru pembina terdiri dari 14 butir pertanyaan. Sedangkan bagi siswa yang mengikuti pembinaan terdiri dari 12 butir pertanyaan.

Data dikumpulkan melalui teknik wawancara yaitu dengan mengajukan pertanyaan secara mendalam (Siregar, 2016). Yang fokus pada permasalahan khususnya terkait pola pembinaan OSN Matematika. Analisis data hasil wawancara dalam penelitian ini berupa analisis jawaban dari pertanyaan yang akan diajukan peneliti kepada subjek penelitian untuk mengungkap pola pembinaan OSN Matematika yang dilakukan di sekolah. Pengecekan keabsahan data dilakukan dengan pengamatan yang tekun dan triangulasi. Triangulasi yang dimaksud 
adalah triangulasi responden. Yang mana dalam penelitian ini dipilih 3 responden dari tiap sekolah, yakni kepala sekolah, guru pembina OSN Matematika, dan siswa yang ikut pembinaan.

Selanjutnya dilakukan pengumpulan informasi menggunakan instrumen yang telah disusun. Masing-masing sekolah dilakukan oleh 2 mahasiswa untuk wawancara dengan ketiga sumber. Untuk kegiatan pengumpulan data ini dilakukan dalam waktu kurang lebih 3 minggu.

\section{Hasil dan Pembahasan}

\section{A. SMP N 1 Ponorogo}

Pengambilan data di sekolah ini terkendala oleh tidak diberikannya ijin dari sekolah karena kesibukan yang tidak dapat diganggu. Namun demikian diperoleh informasi singkat bahwa pembinaan selalu dilakukan tiap tahunnya. Bukti keberhasilan pembinaan yang dilakukan terlihat dari keberhasilan meloloskan siswanya dalam mengikuti OSN tingkat Kabupaten selama 2 tahun terakhir.

\section{B. SMP N 2 Ponorogo}

Pada tahun 2019, sekolah ini menghantarkan 1 siswanya untuk mewakili Kabupaten Ponorogo dalam seleksi OSN tingkat Provinsi. Kepala sekolah memberikan penuturan bahwa ada program khusus di sekolah ini dalam bentuk social academic yang bernama kelas Cerdas Istimewa. Lebih lanjut dijelaskan guru pembina OSN Matematika, bahwa kelas Cerdas Istimewa ini sebagai kegiatan ekstrakurikuler yang dinamakan
Biga Sains Matematika. Melalui kegiatan ini, siswa terpilih dari seleksi, dibina selama satu tahun penuh. Khusus siswa kelas VII, maka seleksi awal dilakukan berdasarkan nilai ujian akhir dari SD atau berdasarkan sertifikat prestasi yang relevan dengan matematika. Kemudian dilakukan seleksi lagi untuk bergabung kelas pembinaan ini.

Sekolah ini mendukung keterlaksanaan pembinaan dengan menganggarkan biaya dalam Rencana Anggaran Pengeluaran Belanja Sekolah (RAPBS). Selain itu, guru pembina juga rajin mengembangkan keahliannya melalui kegiatan bersama MGMP. MGMP pernah mengundang pakar dari perguruan tinggi untuk memberi pengetahuan terkait OSN. Pembinaan dilakukan seminggu sekali oleh guru pembina, yakni guru mapel, berkolaborasi dengan tutor dari luar sekolah. Pihak sekolah juga selalu melakukan evaluasi berkala terhadap keterlaksanaan kegiatan social academic ini.

Menurut salah satu siswa yang ikut dalam pembinaan OSN Mapel Matematika, diperoleh informasi bahwa pembinaan dilakukan di luar jam pelajaran. Seringkali pembinaan dilakukan dengan pemberian soal, lalu siswa diberi kesempatan untuk mengerjakan sendiri selama 30 menit. Kemudian dibahas bersama oleh guru pembina atau tutor. Di semester ganjil, siswa dibina terkait materi-materi sesuai silabus OSN. Sedangkan pada semester genap, siswa diberikan soal-soal latihan persiapan 
mengikuti OSN. Waktu pembinaan di semester genap juga dialokasikan lebih banyak dibanding semester ganjil.

Pemilihan siswa yang diikutkan seleksi tingkat kabupaten adalah hasil dari seleksi terhadap siswa yang telah dibina khusus, yang terdiri dari 3-4 siswa. Sebelum pembinaan khusus ini, dilakukan seleksi umum terhadap siswa-siswa yang tergabung dalam kelas Cerdas Istimewa. Seleksi yang dilakukan dengan memberikan tes kepada siswa, kemudian dipilih nilai tertinggi. Apresiasi sekolah terhadap siswa yang lolos seleksi tingkat kabupaten adalah diberi uang pembinaan, piagam/sertifikat, dan penyerahan tropi saat upacara bendera hari Senin. Sedangkan bagi guru pembina mendapatkan nilai tambah saat penilaian kepegawaian dan kegiatan dinas disampaikan sebagai pembina, jadi reward bagi guru tidak berupa uang.

Apabila ada kesulitan dalam menyelesaikan soal OSN, guru masih bingung untuk bertanya kepada siapa. Siswa mengalami kesulitan juga dalam hal materi karena beberapa belum pernah mereka pelajari di kelas, sehingga terkendala dalam memahami. Namun demikian, upaya yang dilakukan hanya sekedar mengikuti pembinaan di sekolah serta belajar sendiri di rumah. Disebutkan narasumber, dari pihak siswa ini, memang menyukai matematika sejak SD. Oleh karenanya ia mau berusaha mempelajari materi sendiri walaupun belum diajarkan sebelumnya.

\section{SMP N 3 Ponorogo}

Dalam dua tahun terakhir, sekolah ini belum dapat meloloskan siswanya dalam mengikuti OSN tingkat kabupaten. Namun, berdasarkan wawancara dengan kepala sekolah, diperoleh informasi bahwa sebenarnya telah ada program ekstrakurikuler OSN Mapel Matematika. Ektrakurikuler ini diimplementasikan dengan kegiatan pembinaan seminggu sekali. Untuk pembina adalah guru matematika dan juga mendatangkan tutor dari luar, harapan sekolah adalah agar dapat menambah motivasi, variasi, dan pengalaman yang lain. Selain itu, upaya mengembangkan keahlian guru dalam membina juga dilakukan, seperti diikutkan workshop, seminar maupun ikut serta dalam MGMP. Bahkan sang guru mengaku pernah ikut pelatihan yang diselenggarakan provinsi Jawa Timur.

Sarana prasarana yang dibutuhkan juga disediakan sekolah, seperti laptop dan jaringan internet, yang seringkali digunakan untuk mengakses bahan/materi OSN. Untuk siswa yang berhak mengikuti pembinaan adalah siswa kelas 7 dan 8, kelas 7 dipersiapkan untuk tahun berikutnya, sedangkan kelas 8 memang dipersiapkan untuk mengikuti OSN di tahun berjalan. Seleksi awalnya menggunakan angket dan tes tulis, kemudian dipilih siswa yang berminat dan nilai tesnya tinggi. Pembinaan dilakukan dengan memberikan soal dari tahun sebelumnya dan berdasarkan kisi-kisi OSN. Siswa diberi waktu untuk mengerjakan 
sendiri, lalu dibahas bersama. Seluruh materi dalam kisi-kisi dibahas secara keseluruhan. Selain itu siswa menyatakan bahwa dalam pembinaan sudah diberikan materi dan buku rumus-rumus menghadapi OSN Mapel Matematika. Hingga akhirnya dipilih siswa yang mengikuti OSN tingkat kabupaten setelah melewati 5 kali seleksi menggunakan tes.

Apabila ada siswa yang dapat lolos seleksi tingkat kabupaten, maka sekolah memberi reward kepada siswa berupa bebas tanggungan administrasi keuangan selama 1 tahun. Sedangkan bagi guru akan diberikan piagam penghargaan dari sekolah. Meskipun demikian, hasil beberapa tahun terakhir ini diakui kepala sekolah belum sesuai harapan. Guru pembina menyebut kesulitan terbesar adalah siswa input yang kurang bagus, sehingga butuh upaya yang lebih keras. Sedangkan kendala dari siswa adalah belum paham dengan beberapa materi OSN. Walaupun sebenarnya siswa juga telah berupaya untuk belajar di rumah melalui aplikasi Youtube dan dibimbing orang tua.

\section{SMP N 6 Ponorogo}

Pada sekolah ini, seluruh siswa yang berminat terhadap OSN maka diberikan pembinaan dan pelatihan. Pembinaan dilakukan dengan membimbing secara berkala, dua minggu sekali. Akan ditambah menjadi seminggu dua kali saat dua bulan menjelang pelaksanaan OSN tingkat Kabupaten. Guru matematika ditunjuk sebagai pembina utama, namun apabila dibutuhkan maka merekrut pembina dari luar. Ikut serta guru dalam forum MGMP adalah upaya untuk mempersiapkan diri dalam membina OSN. Selain itu, pernah juga mengikuti pelatihan di since center. Namun, sekarang sudah jarang mengikuti pelatihan, hanya mencari materi OSN di buku dan internet saja.

Pembinaan diberlakukan untuk siswa sejumlah 10-15 anak, yang diseleksi oleh guru berdasarkan observasi keseharian dalam pembelajaran di kelas. Sarana yang diberikan sekolah adalah ruangan khusus untuk pembinaan. Sarana prasarana yang disiapkan oleh guru adalah buku-buku OSN dan kumpulan soal-soal OSN tahun lalu. Pembinaan dilakukan dengan latihan soal OSN dari tahun-tahun sebelumnya. Materi yang dibahas keseluruhan, namun diutamakan yang sulit bagi siswa. Trik atau cara cepat dalam menyelesaikan soal OSN juga diberikan oleh guru pembina. Siswa yang diajukan untuk mengikuti OSN tingkat Kabupaten adalah yang lolos minimal 2 kali seleksi. Reward bagi siswa diberikan sekolah kalau lolos seleksi tingkat kabupaten. Untuk guru diberikan cendera mata yang diberikan saat upacara bendera.

Evaluasi kegiatan pembinaan dilakukan setiap tahun. Evaluasi terkait kedisiplinan dalam melakukan program. Juga dilakukan evaluasi terhadap motivasi serta target anak-anak dalam OSN. Kesulitan yang dialami guru dalam membina adalah mengajari siswa untuk menyelesaikan soal yang butuh penalaran, bahkan beberapa 
soal juga dirasa sulit bagi guru pembina. Selain itu, guru dan siswa juga kesulitan dalam mengatur waktu untuk pembinaan.

\section{E. SMP N 1 Jetis}

Siswa sekolah ini selalu mewakili Kabupaten Ponorogo dalam ajang OSN dua tahun terakhir. Bahkan 7 tahun yang lalu, siswa dari sekolah ini mewakili Provinsi Jawa Timur untuk seleksi tingkat nasional. Terdapat ekstrakurikuler yang khusus untuk pembinaan OSN. Pembinaan dilakukan setiap minggu oleh guru matematika sendiri, tanpa menghadirkan tutor dari luar. Untuk mendukung hal tersebut, maka guru pembina OSN diikutsertakan bimbingan teknis. Seleksi awal untuk siswa dapat ikut pembinaan adalah dengan mengisi angket untuk mengikuti pembinaan OSN dengan guru pembina maupun mapel pilihan masingmasing. Kemudian dilakukan tes lanjutan bagi siswa yang telah mengisi angket.

Dukungan sekolah diberikan secara penuh, terlebih terkait finansial. Motivasi untuk siswa juga diberikan oleh pihak sekolah melalui guru pembina. Buku penunjang dengan 5 referensi dan alat peraga matematika KIT disediakan sekolah untuk mendukung kegiatan pembinaan. Guru menyediakan modul dan latihan soal bagi siswa-siswa yang dibinanya. Soal-soal ini terdiri dari soal tahun lalu dan soal yang sudah dimodifikasi oleh guru pembina. Proses pembinaan dilaksanakan selama 90 menit tiap minggunya, yang terbagi menjadi tiga bagian dengan masingmasing 30 menit. Pada 30 menit pertama diberikan teori, lalu dikasih soal latihan, dan 30 menit terakhir untuk membahas soal yang telah dikerjakan. Pemilihan siswa yang diikutsertakan seleksi tingkat Kabupaten adalah dengan tes.

Materi yang dibahas saat pembinaan dikaji secara menyeluruh, dari soal tingkat dasar hingga tingkat tinggi (HOTs). Agar dapat mengembangkan keahlian guru dalam membina, maka guru pernah mengikuti diklat pembina OSN. Menempuh studi lanjut dengan beasiswa yang diberikan sekolah juga mengikuti seminar. Selain itu, guru juga mengikuti Olimpiade Guru Matematika Nasional. Meski demikian, guru pembina mengaku bahwa materi OSN masih di luar kemampuan siswa, sehingga guru sulit untuk mengajari. Pembinaan yang dilakukan 2-3 kali seminggu saat mendekati perlombaan, diakui siswa menyebabkan kurang fokus karena kecapean.

Reward hanya diberikan pihak sekolah apabila siswa mendapat juara, begitu pula untuk guru pembinanya. Apabila siswa lolos seleksi tingkat kabupaten, maka sekolah akan menyediakan biaya akomodasi dan uang saku. Imbalan bagi guru akan diberikan jika siswa juara 1 maka diberi uang sebagai reward. Evaluasi pelaksanaan program pembinaan OSN dilakukan dengan melihat kekurangan dan memperbaiki kesalahan yang dilakukan tahun sebelumnya. Evaluasi ini juga berdasar ketercapaian target, apabila telah 
tercapai maka target ditingkatkan, jika belum maka dilakukan perbaikan.

\section{F. SMP N 1 Bungkal}

Dua tahun terakhir, sekolah ini belum beruntung untuk meloloskan siswanya dalam seleksi tingkat kabupaten. Berdasarkan informasi dari kepala sekolah, awal tahun ajaran dilakukan seleksi tim OSN Matematika. Peserta yang diseleksi adalah siswa kelas 7 dan 8. Siswa yang terpilih kemudian diberikan pembinaan secara rutin tiap minggunya. Pembinaan biasanya dimulai bulan Oktober hingga menjelang pelaksanaan seleksi tingkat kabupaten. Apabila sudah dekat perlombaan, maka dilakukan seleksi kembali hingga terpilih 1 anak untuk mewakili sekolah. Kemudian 1 anak ini dibina secara intensif kurang lebih 10 kali sebelum pelaksanaan seleksi tingkat kabupaten.

Untuk pembinanya, sekolah mempercayakan kepada guru mata pelajaran matematika. Untuk mendukung hal tersebut maka guru mengikuti seminar, diberikan buku referensi, hingga mencari referensi dari internet. Yang mana sekolah sudah menyediakan referensi dan wifi guna mendukung pengembangan keahlian guru pembina. Apabila siswa lolos seleksi tingkat kabupaten, maka diberi reward berupa buku referensi, alat perlengkapan sekolah, dan piagam penghargaan. Dengan adanya pelaksanaan OSN tingkat kabupaten ini, SMP N 1 Bungkal berharap dapat dijadikan ajang berkompetisi yang baik untuk seluruh sekolah di Kabupaten Ponorogo.

\section{G. MTs N 1 Ponorogo}

Sekolah ini mempunyai program khusus yang diberi nama BIO (Bimbingan Insentif Olimpiade). Bimbingan ini dilakukan tiap seminggu sekali. Sebagai pembina adalah guru matematika yang sudah mengikuti diklat OSN, sedangkan sebulan sebelum lomba mendatangkan bantuan tutor dari Bimbel Champion (Go). Bahkan siswa mengaku diikutkan bimbel di Primagama dengan biaya ditanggung sekolah. Hingga 2 tahun lalu, sekolah ini mampu menghantarkan siswanya untuk mewakili Kabupaten Ponorogo mengikuti seleksi tingkat provinsi. Guru pembina juga aktif mengembangkan keahlian dalam hal membina dengan mengikuti berbagai diklat, ikut serta MGMP KSM Grup seIndonesia dan Olimpiade Guru.

Seleksi bagi siswa yang mengikuti OSN adalah dengan dilakukan screening. Pembinaan dilakukan dengan kegiatan ceramah, pemberian soal, dan diskusi berpedoman pada silabus OSN. Demi mendukung optimalisasi pembinaan maka disediakan koneksi internet, buku diktat olimpiade, dan pembuatan soal oleh guru sendiri. Materi pembinaan dibahas secara menyeluruh sesuai silabus OSN. Secara garis besar, pembinaan dilakukan dengan memberikan soal dan membahas materi yang belum jelas. Kemudian dilakukan tes kembali pada siswa yang tergabung dalam BIO, dan diambil siswa dengan nilai 
tertinggi untuk mewakili sekolah dalam seleksi tingkat kabupaten.

Reward yang diberikan ke siswa berupa uang saku, piala duplikat, beasiswa prestasi dan diikutkan bimbel untuk memperdalam materi OSN. Sedangkan bagi guru diberi imbalan berupa sertifikat, diikutkan workshop, dan reward berupa barang dari sekolah. Guru mengalami kesulitan mengajari siswa pada materi analisa penalaran dan kombinatorika. Sedangkan siswa mengalami kesulitan karena merasa materi OSN berbeda jauh dengan materi di kelas, terlebih pada materi penalaran. Oleh karena hal itu, siswa mengaku belajar mandiri di rumah karena ingin sukses mengikuti seleksi OSN demi membanggakan orang tua.

\section{H. MTs N 3 Ponorogo}

Sekolah ini telah memiliki program OSN walaupun belum lama dibentuk, yakni baru sekitar 3 tahun. Program inipun baru dibentuk saat mendekati pelaksanaan OSN. Waktu pembinaan juga belum terjadwal, hanya menunggu waktu luang dari guru pembina. Berdasarkan informasi kepala sekolah bahwa belum pernah ada siswa yang lolos seleksi tingkat kabupaten. Namun demikian, pembinaan OSN tetap eksis dan dikembangkan. Pembina utama kegiatan ini adalah guru matematika. Selain itu, kadangkala didatangkan pembina dari luar sekolah untuk menambah wawasan dan pengalaman serta trik penyelesaian soal-soal. Guru pembina selama ini melakukan upaya pengembangan keahlian sebatas bergabung dengan grup pembina KSM. Akan tetapi dalam hal membina OSN, hanya sekedar berbagi pengalaman dari guru pembina mapel lain di sekolah yang telah berpengalaman.

Proses penyeleksian siswa adalah berdasar rekomendasi guru matematika, karena dirasa cukup mengetahui potensi yang dimiliki siswa. Demi keterlaksanaan pembinaan, sekolah memberi dukungan penuh baik moral maupun materil. Pembinaan dilakukan dengan cara memberikan soal-soal latihan kepada siswa yang kemudian dibahas bersama. Selain itu mengambil materi dari buku referensi dan mengunduh dari internet. Uniknya, untuk seleksi siswa yang diikutkan seleksi tingkat kabupaten prosesnya adalah perwakilan terbaik dari masing-masing kelas.

Pemberian apresiasi bagi siswa yang lolos seleksi tingkat kabupaten diberi penghargaan, seperti dipanggil saat upacara bendera, juga materil. Sedangkan bagi guru diberi sertifikat dan materil sesuai kemampuan sekolah. Kesulitan yang dialami guru adalah pemahaman materi siswa yang masih kurang, soal OSN tingkat kesulitan cukup tinggi, dan pembagian waktu karena kesibukan mengajar. Kesulitan siswa hanya merasa pesimis dan tidak percaya diri dalam mengikuti OSN. Untuk memupuk rasa percaya diri, siswa mengikuti les tambahan di luar sekolah. Evaluasi kegiatan pembinaan juga dilaksanakan tiap tahunnya. 
Berdasarkan hasil yang diperoleh tersebut, dapat disimpulkan bahwa seluruh sekolah sampel telah melakukan pembinaan OSN Mapel Matematika. Dari sekolah yang siswanya mewakili Kabupaten Ponorogo dalam OSN tingkat Provinsi rentang dua tahun terakhir, pembinaan rutin dilakukan selama tahun ajaran dengan jadwal yang teratur. Sedangkan sekolah yang masih belum berkesempatan lolos seleksi tingkat kabupaten, cukup beragam dalam melaksanakan pembinaan. Ada yang rutin dan terjadwal selama tahun ajaran, ada juga yang rutin dan terjadwal namun hanya dilakukan mendekati OSN, terdapat pula sekolah yang belum mempunyai program secara rutin dan terjadwal. Hasil ini relevan dengan hasil pengabdian oleh Mardiyana, dkk. (2016), yang menyimpulkan bahwa pembinaan olimpiade bagi siswa, khususnya bidang matematika, perlu dikelola oleh guru dengan baik, kontinu, dan berkesinambungan. Nyatanya sekolah yang melakukan program pembinaan dengan teratur dapat mewakili Kabupaten Ponorogo dalam OSN tingkat Provinsi.

Beberapa kendala yang dialami baik oleh guru maupun siswa yang ikut pembinaan OSN. Sebagian besar mengaku kesulitan dalam memahami materi OSN yang memang tingkatannya lebih tinggi dibanding materi di kelas. Namun, beberapa mengatasi hal ini dengan belajar mandiri di luar jam pembinaan, baik sendiri maupun di bimbel. Selain itu, kegiatan pembinaan didominasi dengan proses pengerjaan soal-soal latihan OSN. Yang mana soal ini sebagian besar guru pembina adopsi dari soal pada tahun sebelumnya. Tujuannya adalah sesuai dengan pendapat Kusuma (2010), yakni agar siswa memiliki ketekunan, kreativitas, komunikatif, dan pemahaman konsep dalam persiapan menuju olimpiade.

Pembinaan OSN Mapel Matematika tingkat SMP di Kabupaten Ponorogo dilakukan terhadap siswa yang lolos seleksi awal tingkat sekolah. Seleksi awal ini dilakukan dengan metode yang beragam. Dapat disimpulkan beberapa metode yang digunakan, meliputi tes tulis, angket, maupun rekomendasi dari guru mapel Matematika. Ini artinya, pembinaan yang dilakukan memang untuk meningkatkan kemampuan, daya saing maupun kreativitas yang dimiliki siswa dalam menghadapi OSN. Hasil ini sesuai dengan pendapat dari Soetopo \& Soemanto (dalam Hamdan, 2014); Kurniawati (2014) terkait definisi pembinaan.

Secara umum hasil penelitian ini adalah proses pembinaan OSN Mapel Matematika dilakukan dengan sistem pendampingan secara berkala. Sejalan dengan Fauzan \& Dzikrullah (2018) yang memilih metode yang sama dalam melakukan pembinaan. Sedangkan ditinjau dari pendapat Enung (2008), yang menyatakan pola pembinaan ada tiga jenis, yakni otoriter, permisif, dan demokratis, maka hasil penelitian ini adalah ketiga pola tersebut diterapkan oleh sekolah tingkat SMP di Kabupaten 
Ponorogo dalam pembinaan OSN. Hasil penelitian dapat dilihat pada Gambar 1.

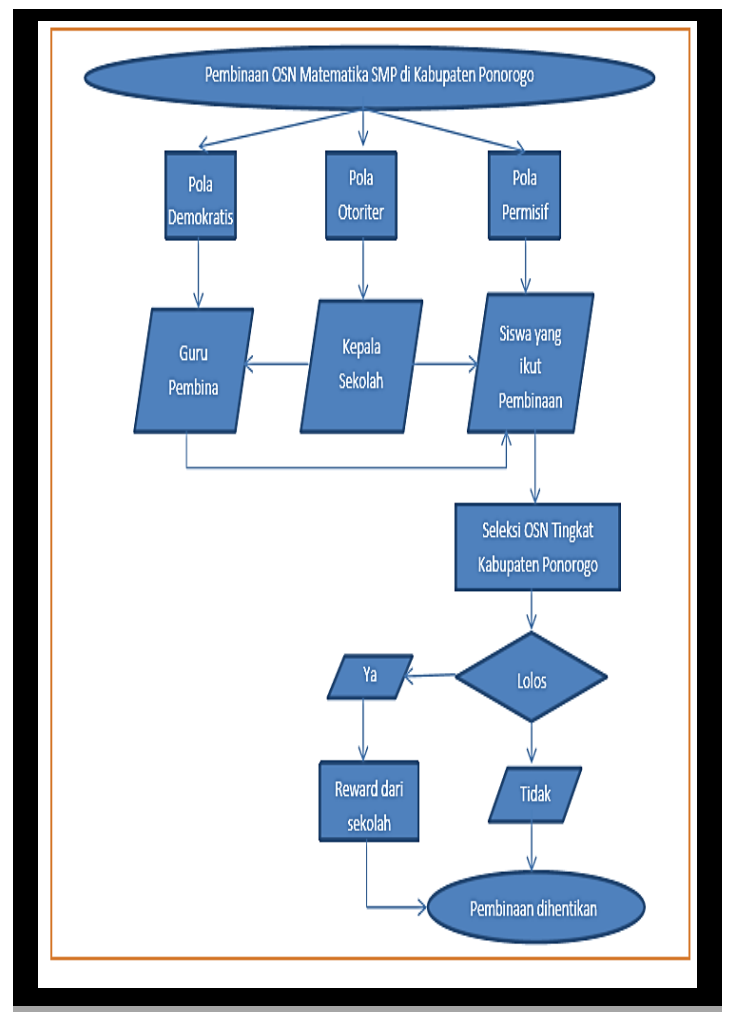

Gambar 1. Pola Pembinaan OSN Matematika di Kabupaten Ponorogo.

\section{Penutup}

Pola pembinaan OSN Matematika SMP di Kabupaten Ponorogo dilakukan dalam tiga pola pembinaan, yakni otoriter, permisif, dan demokratis. Pada pola otoriter, terlihat dari kebijakan sekolah dalam menyusun program pembinaan, proses seleksi, hingga reward yang diberikan. Pola permisif terlihat dari kegiatan pembinaan yang memberikan kesempatan bagi siswa secara terbuka untuk menambah kemampuan di luar pembinaan yang dilakukan di sekolah. Terakhir adalah pola demokratis, sangat terlihat saat sebagian besar proses pembinaan diawali dengan pemberian materi, lalu siswa diberi kesempatan untuk menyelesaikan soal latihan yang diberikan secara mandiri atau kelompok.

\section{UCAPAN TERIMA KASIH}

Terima kasih penulis sampaikan kepada Universitas Muhammadiyah Ponorogo yang telah mendanai penelitian ini.

\section{DAfTAR Pustaka}

Afriansyah, E. A. (2016). Penggunaan Software ATLAS. ti sebagai Alat Bantu Proses Analisis Data Kualitatif. Mosharafa: Jurnal Pendidikan Matematika, 5(2), 53-63.

Arifin, M. (2008). Hubungan Timbal Balik Pendidikan Agama. Jakarta: Bulan Bintang.

Budiono, I., dan Suhendar, U. (2019). Meningkatkan pemahaman konsep matematika siswa melalui pendekatan RME. Prosiding Seminar Nasional Pendidikan dan Pembelajaran 2019, 488-495.

Departemen Pendidikan Nasional. (2008).

Kamus Besar Bahasa Indonesia. Jakarta: Pusat Bahasa.

Enung, F. (2008). Psikologi Perkembangan: Perkembangan Peserta Didik. Bandung: Pustaka Setia.

Faturohman, I., \& Afriansyah, E. A. (2020). Peningkatan Kemampuan Berpikir Kreatif Matematis Siswa melalui Creative Problem Solving. Mosharafa: Jurnal Pendidikan Matematika, 9(1), 107-118. 
Fauzan, A., \& Dzikrullah, A. A. (2018). Optimalisasi kecerdasan siswa dengan intensitas pembinaan olimpiade matematika. AJIE - Asian Journal of Innovation and Entrepreneurship, 3(3), 209-216.

Hamdan. (2014). Pengembangan kurikulum Pendidikan Agama Islam (PAI) teori dan praktik. Banjarmasin: IAIN Antasari Press.

Hartawan, I. G. N. Y., Suryawan, I. P. P., \& Gita, I. N. (2017). Peningkatan Kompetensi Guru Dalam Bidang Olimpiade Matematika Tingkat SMP. SENADIMAS 2017, 404-408.

Kurniawati, M. (2014). Kajian Motivasi Belajar Mandiri Siswa Melalui Pembinaan dan Pendampingan Olimpiade Sains Nasional (OSN) Bidang Kimia pada Siswa. Jurnal Inspirasi Pendidikan Universitas Kanjuruhan Malang, 4(1), 446-455.

Kusuma, J. (2010). Pembinaan Olimpiade Matematika. JMSK, 6(2), 86-91.

Mardiyana, Riyadi, Sujatmiko, P., \& Aryuna, D. R. (2016). Peningkatan kompetensi guru matematika SMP Kota Surakarta dalam pembinaan olimpiade matematika nasional. Prosiding Seminar Matematika dan Pendidikan Matematika, 848-860.

Munandar, H. (2018). Pola pembinaan keagamaan di SMA plus boarding school Astha Hannas Subang. Jurnal Tarbiyah, 25(1), 20-39.

Siregar, N. (2016). Meninjau Kemampuan Penalaran Matematis Siswa SMP melalui Wawancara Berbasis Tugas

Geometri. Mosharafa: Jurnal Pendidikan Matematika, 5(2), 128137.

Yunita. (2014). Pola pembinaan International Junior Science Olympiad (IJSO) IPA di tingkat nasional. Edusains, 6(1), 10-16.

\section{Riwayat Hidup PenUlis}

\section{Uki Suhendar, M. Pd.}

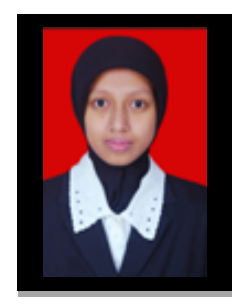

Lahir di Ponorogo, 29 Oktober 1990. Staf pengajar di Universitas Muhammadiyah Ponorogo. Studi S1 Pendidikan Matematika Universitas Muhammadiyah Ponorogo, lulus tahun 2012 dan S2 Pendidikan Matematika Universitas Negeri Yogyakarta, lulus tahun 2015.

\section{Arta Ekayanti, S.Pd., M. Sc.}

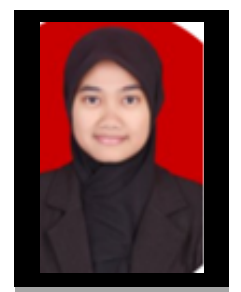
Lahir di Magetan, 18 Januari 1991. Staf pengajar di Universitas Muhammadiyah Ponorogo. Studi S1 Pendidikan Matematika Universitas Muhammadiyah Ponorogo, lulus tahun 2012 dan S2 Matematika Universitas Gadjah Mada, Yogyakarta, lulus tahun 2015.

Senja Putri Merona, S. Si., M. Pd.

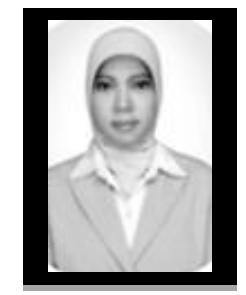

Lahir di Bojonegoro, 17 Juni 1990. Staf pengajar di Universitas Muhammadiyah Ponorogo. Studi S1 Matematika Universitas Negeri Malang, lulus tahun 2012 dan S2 Pendidikan Matematika Universitas Negeri Malang, lulus tahun 2015. 